\title{
The Exploration of Teaching Mode of Flipped Classroom in College English Teaching
}

\author{
Xiaoqian Kang \\ School of Foreign Studies, Xi'an University, 710065
}

Keywords: Flipped classroom; Teaching mode; College; English teaching; Exploration

\begin{abstract}
With the continuous progress of social economy, the new educational concept begins to emerge. Compared to the traditional teaching mode, the new teaching mode, namely flipped classroom, begins to appear frequently in the university and college classroom. The most attractive part of flipped classroom is that it can make students learn independently, pay more attention to cultivate students' interest in learning, and play an important role in improving the quality and effect of college English teaching. Therefore, this paper will explore the new teaching model - flipped classroom in in college English teaching. Through the study of some existing cases, we can find that the use of flipped classroom in college English classroom teaching can effectively improve students' ability of dictation, reading, translation and self-study. At the same time, the emergence of the mode is investigated and found that most students hold an accepted attitude of the new teaching model, and this new teaching mode stimulates students' passion and interest to learn English from the deep level. Author hopes to provide some reference for promoting the quality of college English teaching.

Flipped classroom is put forward by two high school chemistry teachers of the United States. The two teachers combined the PPT demo video with classroom real-time explanation organically and uploaded to the Internet, thus attracting people's attention. The novelty of flipped classroom is that it is completely unrelated to the traditional teaching mode. Thereafter, this teaching mode has been promoted by a lot of colleges and universities. Therefore, it gradually spreads to the the teaching class of many colleges and universities, especially in college English teaching class, which provides a new perspective for English teaching. Therefore, this paper will explore the application of flipped classroom teaching mode in college English teaching. The basic content of the flipped classroom mode will be elaborated below:
\end{abstract}

\section{The Basic Content of Flipped Classroom Mode}

\section{A B rief Introduction to the Concept of Flipped Classroom}

The traditional teaching process is that the teachers teach students the knowledge of the book in the classroom time, and assign students homework after school. Students only need to complete the tasks that teachers arranged. While as a new type of teaching mode, flipped classroom is completely the opposite with the traditional teaching mode. Based on the development of information, flipped classroom is accepted by masses. The teachers provide students with learning resources, but are mainly teaching videos. So students need to watch this kind of videos before class, and classroom time is mainly used to explore and communicate; the main purpose is to improve the overall teaching effect and students' learning efficiency. All in all, flipped classroom teaching mode is an important way to promote the quality of college English teaching.

With the continuous progress of social economy, the level of information technology is also increasing, therefore, the use of information technology in the field of education has become the inevitable result of the development, and flipped classroom teaching mode will naturally be fully utilized in the field of education. With the progress of the times, students begin to use the network to search and effectively use high-quality educational resources, rather than just rely on teachers to impart knowledge. In short, the role of the classroom and the teachers has changed. In the development of new teaching mode, the teacher's primary responsibility is to answer the questions and guide students to correctly use knowledge. 


\section{The Teaching Process of Flipped Classroom Mode}

The main teaching process of flipped classroom is: students self-learning - self-practice - teacher answering questions and guiding - summary. The traditional teaching mode is: the students preparing textbooks before class - teacher explaining in the classroom - self-practice after-school. Compared with the two teaching models, it can be clearly found that the former has advantages either in the design of learning process or in the design of organizational aspect. The independent learning process of flipped classroom needs teachers to do planning work in advance, such as the designing solutions and processes, finding relevant learning materials and the corresponding after-school exercises, etc., and share these plans on the platform to make students learn independently so as to not only promote students to take the initiative to learn, but also better guide the learning ideas of students.

\section{The Advantages of Flipped Classroom Teaching Mode}

\section{Optimizing the Teaching Structure and Promoting Individual Teaching}

The main feature of traditional teaching model is the teacher to use only 45 minutes of class to impart knowledge to the students at the greatest extent, which is a teacher-based one-way transmission. The biggest drawback of this teaching mode is that teachers want to be able to impart knowledge to students at the greatest extent, but ignore the differences between students and the ability of students to accept knowledge, so it is difficult to achieve the desired effect of the teachers. In addition, there are some differences in the basic skills among the students and psychological cognitive ability. Simply teaching with the classroom time is difficult to treat students differently, so it cannot meet the different needs of students. And the new teaching mode flipped classroom is a very good solution to the problem of self-learning and individualized guidance of teachers. This teaching mode can not only achieve the purpose of teachers to impart knowledge, but also consolidate the understanding and absorption of knowledge for students. In the college English teaching classroom, to train students' listening ability, teachers often play recording randomly in the classroom to practice the listening and writing ability of students, but this training has occupied a lot of classroom time and ultimately makes the class time less effective use with ineffective teaching. However, the emergence of flipped classroom is a good solution to solve the problem. Teachers can reasonably adjust the teaching structure so that students can use extra-curricular time for training of dictation. At the same time, students may more or less have some differences in the English dictation, and we analyze that many reasons can lead to this result. Therefore, students can make good use of extracurricular time to sum up and analyze to find out their own problems and shortcomings, such as inaccurate pronunciation and less training, and then they can talk with the teacher to work together to find a solution in class. Students use extracurricular time to study and train, while in class time, the teacher needs a series of examination on the learning results of the students, and then answers the questions from the students, thus to enhance the teaching effect.

The shortcomings of the traditional teaching mode are just complementary with the advantages of flipped classroom, which fully mobilize the students' learning passion and interest, making the students become the main body of the classroom. Students can choose different focuses to learn after class, and can choose their own interest in learning to enrich their learning atmosphere. At the same time, there is more time for students with teachers to conduct one-on-one counseling and exchange, so as to meet the different needs of each student and ultimately achieve the value of the classroom and the concept of individualized teaching.

\section{Advocating Diversity Interaction and Enhancing Relationship between Students and Teacher}

The traditional teaching mode is based on the teacher as the main body. Teachers have absolute right to speak and control in class, and as students, they need to obey every arrangement and link of the teacher in the classroom. Teachers and students belong to a subordinate relationship, and students cannot question the teacher or argue with the teacher, which therefore to a large extent 
inhibits the development of students, hinders the development of student thought, and is not conducive to cultivate the feelings between students and teachers. This form of development is the worst for the teaching of English knowledge, which will hinder the training and development of students' English language skills. In the new teaching mode flipped classroom, the above form does not exist at all. Students and teachers are in equal position; the teacher is not the classroom controller any more, but is the guider and learning partner of the students. Classroom teaching mode also changes from the initial one-way teaching into the current two-way learning, which is very good to promote the exchange of teachers and students in the interaction. Students can not only ask questions to teachers and express their views, but also explore with the classmates, and ultimately the classroom becomes a place of discussion and communication between teachers and students or among students, which effectively enhances the feelings between teachers and students. In the process of communication for teachers and students, the communication skills and creative thinking of students can obtain a good promotion, and students' understanding of knowledge can also have a certain increase. Equal and active classroom atmosphere effectively narrows the connection between students and teachers, and also correspondingly reduces the anxiety atmosphere in the English class, making students be more willing to use English to communicate.

\section{Integrating High Quality Resources and Promoting Educational Fairness}

At present, China's teaching resources distribution is obviously uneven; most of the high quality teaching resources exist in a small number of elite schools, which keeps many students away from the resources. And the emergence of new teaching mode flipped classroom is a good solution to solve the problem of resource allocation. In the lesson preparation, teachers can collect the teaching resources of many elite schools through the Internet platform for induction and integration, and then put in their own teaching class so that students can enjoy high quality resources, thus to shorten the differences between the various regions and make up the situation of poor English teaching due to differences existed in teaching structure and teaching mode. The biggest advantage of flipped classroom is to share a variety of high quality learning resources with Internet. With the continuous progress of Internet technology, more and more children can enjoy the high quality teaching resources, and which truly achieves the goal of fair education.

\section{The Practical Application of Reversing Classroom Model in College English Teaching}

\section{Improving Students' Ability to Use English Promoting the Ability of Listening, Writing and Translation}

The relevant follow-up surveys of the universities on the implementation of the flipped classroom teaching mode have been performed. After a period of time of the implementation, the same difficulty of test is established to the students, and it can be clear found that the students' grades are significantly improved compared with those before the implementation of flipped classroom teaching mode, especially the students' listening, writing and translation. As English is an autonomous language course, students only have their own interests and passion can they effectively improve the English learning effect. The emergence of flip classroom is just in line with the requirements of students that they are free to choose their favorite to learn and to understand, which in short, invisibly enhances the students' learning ability.

\section{Promoting the Ability of Speaking and Reading}

Speaking is a key point in English teaching, but according to the results of the survey, the results are far from the expectations. Students' spoken ability has a great contact with whether the students are willing to speak English. In the traditional teaching mode, the teacher is the subject of the class, while the students are relatively in a passive state, so the students did not show too much enthusiasm for learning English. The emergence of the new teaching mode flipped classroom has changed the status of students and teachers in class. Students will become the main body of the 
class and can express their views. Besides, students need to do a report regularly based on their own learning situation, and communicate with the teachers in the class. In addition, students should also use English more to communicate in the common life, which is beneficial to the improvement of students' reading ability. According to the survey, it can be found that if a person often uses English for communication, after a period of time, his English reading ability will be significantly improved.

\section{Mastering the Ability to Improve the Terminology}

Professional terminology is a difficult point to learn English; it can also examine students' English practical ability, therefore, it is often used as a test point of investigation. According to the survey results, it shows that after a period of time of flipped classroom teaching, it can be found that students' ability to use professional terms has been significantly improved before and after their writing. Therefore, it can be found that the use of new teaching mode flipped classroom can deepen the impact of students on professional terms, so as to enhance the usage rate and mastery of the professional terms. Correspondingly, it can be found in the surveyed population that students who are passionate and interested in English have a significant improvement in their ability to use professional terminology after contacting the flipped classroom teaching mode.

\section{Enhancing the Ability of Self-recognition}

For some students who have experienced the flipped classroom teaching mode, their English proficiency has been significantly improved, especially in listening and speaking. In addition, they have a comprehensive understanding on overall understanding of English and knowledge of English subject. Taking the translation ability as an example, students will possess an overall understanding in academic communication, vocabulary mastery and vocabulary.

\section{Improving the Level of Students' Recognition}

Investigations have been implemented for universities and colleges adopted flipped classroom teaching mode. According to the results, it shows that students who have come into contact with flipped classroom have accepted the attitude of this new type of teaching mode, and the students' listening, writing, translation, reading abilities, etc. and other professional abilities have obtained some improvements, which have a greater academic help for students.

\section{Conclusion}

To sum up, the university's teaching philosophy is completely different from the spoon-fed education of the primary and secondary schools. The universities pay more attention to self-learning, and its exploration and purpose are more strongly. The teaching mode of the universities is to achieve the purpose of teaching through the active learning of the students in the highly study environment, and the teaching of the combination of practice theory in the outside world is better than that of the classroom teaching. Especially for English teaching, the superiority of this flipped classroom teaching mode is far greater than a single spoon-fed teaching. Therefore, this flipped classroom teaching mode and its entire process has good development prospects in the current university education.

\section{References}

[1] H. Qiu and K. Zhao: The implementation strategy of the teaching mode of flipped classroom in college English elective course. Journal of Qiqihar University (Philosophy and Social Sciences), Vol. 01 (2014), p. 159. (In Chinese) 
[2] M. Peng: The application of flipped classroom and micro - course teaching in college English reading and writing. Journal of Hubei University of Economics (Humanities and Social Sciences), Vol. 02 (2015), p. 208. (In Chinese)

[3] X.Y. Yu, Q. Zhang, Z.R. Cai: Research on the application of flipped classroom teaching mode in Computer English teaching. Journal of Huaibei Vocational and Technical College, Vol. 02 (2015), p. 30. (In Chinese)

[4] H. Shao and H.Q. Yu: A study on the design of college English teaching mode flipped classroom based on pan-learning resource sharing platform. Foreign Language Teaching in Shandong Province, Vol. 03 (2015), p. 37. (In Chinese)

[5] X.M. Hu: The application and thinking of the teaching mode of flipped classroom in college English teaching - A case study of Chinese National Culture English Appreciation course. Journal of Linyi University, Vol. 05 (2015), p. 71. (In Chinese)

[6] L. Liu: The application and research of flipped classroom teaching mode in English teaching in medical colleges and universities - Taking Academic English course as an example. China Continuing Medical Education, Vol. 07 (2016), p. 11. (In Chinese)

[7] T.T. Lv and N. Wang: Research on the teaching mode of the flipped classroom based on the SPOC + digital teaching resource platform - Taking college English as an example. China Electrification Education, Vol. 05 (2016), p. 85. (In Chinese)

[8] L. Luo: The application of flipped classroom in college English listening and speaking teaching - A case study of New Visual Field English Listening and Speaking Course. English Square, Vol. 11 (2015). (In Chinese)

[9] N. Geng: An empirical study on the teaching mode of college English listening based on the perspective of micro - course. Journal of Inner Mongolia Normal University (Education Science Edition), Vol. 09 (2016), p. 128. (In Chinese)

[10] D.M. Fu and Gulimira A: Based on the background of college English teaching reform. Journal of Kaifeng Institute of Education, Vol. 10 (2016), p. 63. (In Chinese)

[11]L.X. Jiao, C.L. Ren, C.J. Lv: A feasibility study on the flipped classroom mode of ICLASS platform in college English writing teaching. Journal of Beijing University of Posts and Telecommunications (Social Science Edition), Vol. 01 (2017), p. 87. (In Chinese)

[12] Q.X. Zeng and L.P. Xie: An analysis of college English teaching model based on multimedia and network - A case study of WebQuest teaching mode and flipped classroom teaching mode. English Square, Vol. 01 (2016). (In Chinese) 